\title{
Foreign Capital Flows and Growth of the Nigeria Economy: An Empirical Review
}

\author{
Michael Chidiebere Ekwe ${ }^{1} \&$ Oliver Ikechukwu Inyiama ${ }^{1}$ \\ ${ }^{1}$ Department of Accountancy, Enugu State University of Science and Technology, Enugu State, Nigeria \\ Correspondence: Michael Chidiebere Ekwe, Department of Accountancy, Enugu State University of Science and \\ Technology, Enugu State, Nigeria. E-mail: ekwemike@yahoo.com
}

Received: January 17, 2014

Accepted: February 26, $2014 \quad$ Online Published: March 25, 2014

doi:10.5539/ijef.v6n4p103

URL: http://dx.doi.org/10.5539/ijef.v6n4p103

\begin{abstract}
The volume of investment capital flows between foreign nationals and developing nations has necessitated that a study be conducted to assess the impact of this foreign capital flows on the economic growth of these developing nations. This paper therefore aims at empirically determining the extent to which foreign capital flows have impacted on the growth performance of the Nigeria economy from 1982-2012. Data were drawn from the publications of the Nigerian Bureau of Statistics (NBS), the Central Bank of Nigeria (CBN) and the World Bank report. The multiple regression analysis method was adopted for the test of the hypotheses. The SPSS statistical software (version 17.0) was used for the data analysis. From the results of the analysis, it was discovered that Foreign Capital Inflows had a positive and significant effect on economic growth as proxied by the GDP, which is an indication that foreign capital inflows exerted considerable influence as a key fiscal policy instrument of economic growth over the stated period. Also the Foreign Capital Outflow in the same vein had a positive and significant effect on the GDP, which is another indication that it exerted considerable influence as a key fiscal policy instrument of economic growth over the stated period. Furthermore, the Openness of the economy, which was another explanatory variables used to ascertain the growth performance of the economy, had a positive and significant effect on the GDP. On the other hand, the Human Capital Development had a negative and insignificant effect on the GDP. The implication is that it did not exert much influence on economic growth over the stated period. Finally, the inflation rate had a positive sign with GDP. It was however; statistically insignificant which points to the severity of the inflationary pressure brought to bear on the economy over the stated period. The paper concludes that policy on foreign capital flows should be vigorously pursued and enhanced to provide a buffer to the nations dwindling internally generated revenue (IGR) amidst astronomically growing population.
\end{abstract}

Keywords: foreign capital flows, economic growth, Nigeria economy

\section{Introduction}

The ongoing reforms in most developing economies such as Nigeria ranging from banking sector, public sector to private sector reforms leaves no one in doubt that foreign capital flow is a critical factor to contend with in this adventurous expedition for economic growth and development. In Nigeria context, it is crystal clear that the state and local government cannot be sustained by their internally generated revenue (IGR) because of the low level of their IGR. Consequently, they need inflows from the federation account by means of monthly allocation to supplement the fund generated internally. Nigeria economy needs foreign capital inflows and outflows to stimulate the desired level of growth of her unstable economy.

Foreign capital flows is defined by Nkoro and Furo (2012) as consisting of the movement of financial resources from one country to another; not minding the direction which could be either ways. IMF (1999) however defined workers remittance as consisting of goods or financial instruments transferred by migrants living and working abroad to residents of the home economies of the migrants. It is limited to transfers made by workers who have stayed in foreign economies for at least one year while transfers from migrants that are self employed are excluded. The Economies of least developed countries (LDCs) such as Nigeria as opined by Ezirim, Anoruo and Muoghalu (2006), have been bedeviled by the twin economic crises of mounting debt burden and foreign investment inadequacies accompanied by more than proportionate foreign direct investment income remittance out of these economies and that the debt problem is incredibly odious and appears to have no remedy. In his own 
study, Englama (2007) emphasized that the phenomenal growth of remittances in recent times has caught the attention of governments particularly in the developing countries, international organizations, Non-Governmental Organizations (NGOs) and the private sector, due to its importance as a viable source of external financing. He added that workers' remittances have outperformed some traditional capital inflows such as foreign direct and portfolio investments in several countries while it has become a major source of foreign exchange for others.

Generally, as opined by Aurangzeb and UI Haq (2012), foreign capital inflows depend on a variety of features of the host economy which include among others; its market size, level of education, institutional environment, tax laws, and overall macroeconomic and political environment. Nigeria is the largest recipient of remittances in Sub-Saharan Africa (Hernandez-Coss \& Bun, 2006). Some researchers and school of thoughts also enlisted economic circumstances prevalent in home country, wage, exchange and inflation rates, socio-political, socio-economic and legal environment, cultural and emotional attachments etc as factors of great concern. The Nigerian environment is characterized by very unstable political environment, low level of education, numerous obsolete tax laws without machineries on ground for enforcing compliance and many other critical macroeconomic issues. In our own context, foreign capital flows includes the aspect of inflows consisting export earnings and workers' remittances and the aspect of outflows consisting external debt servicing and foreign aids in the form of Nigeria's financial exposure to peace keeping missions.

However, Iheke (2012) maintains that Nigeria faces immense challenges in accelerating growth, reducing poverty and meeting the Millennium Development Goals (MDGs). Unfortunately as Nkoro and Furo (2012) puts it, the growth experience of many of the economies such as Nigeria has not been very satisfactory and as a result, they accumulate huge external debt in relation to gross domestic product and face with serious debt servicing problems in terms of foreign exchange flow and also walloping in abject poverty. It has also been argued in the literature, Udah (2011), that remittances provide a substantial sources of foreign exchange earnings, which could be used to finance imports, and therefore useful in stabilizing balance of payments in some countries. Ezirim, Anoruo and Muoghalu (2006) observed that foreign investors come in with a small amount of money, which is further magnified by the depreciating exchange rates, and end up carting away huge sums of money out of the host countries in form of investment income. In addition, these funds are reinvested in the capital markets of developed countries to the detriment of domestic markets and the resulting capital flight further exacerbates the crisis relating to the generation of foreign investment income.

In view of this background, this paper examines the impact of inflows and outflows of foreign capital on the growth and development of Nigeria economy during the period under review. The variables under consideration are export earnings, workers' remittances, external debt servicing, foreign aid emanating from Nigeria and economic development of Nigeria proxied by GDP (Gross Domestic Product). To achieve this objective, the remaining part of this paper is organized into four sections. Section two centers on the review of related literature, Section three presents the methodology and models for data analysis and Section four provides the discussion of empirical results while Section five concludes.

\section{Review of Related Literature}

Using the concept of co-integration, variance decomposition, impulse response analysis and block Exogeneity tests, Nkoro and Furo (2012) examined the impact of foreign capital inflows on economic growth in Nigeria. The results of the co-integration revealed that causal relationship exist between foreign capital inflows and economic growth in Nigeria. The variance decomposition result supports that of co-integration analysis of causality which revealed that, causality runs from foreign aid, remittance (RMC), external debt (TED) and foreign direct investment (FDI) to real GDP (growth). Responses of the real GDP to one standard deviation innovations of the components of foreign capital inflows was observed to appear to be very sensitive. The shocks appear to be very pronounced within the forecast period. However, the block of exogeneity tests show that the granger causality runs from remittance (RMC) and external debt (TED) to real GDP (growth) only. Only remittance (RMC) and external debt (TED) are significant. But jointly they all enter the model. However, the result of the error correction model shows that there is a significant positive relationship between foreign aid and real GDP while remittance and real GDP have a negative relationship. FDI and real GDP share a positive relationship while external debt also associates negatively with real GDP. It takes sometime before their impacts are manifested except FDI.

There are indications that non-subsistent remittances are channeled into the stock market, further entrenching the financial supermarket tendencies in the Nigerian economy. Estimates indicate significant leakages for remittance. Proceeds through imports, possibly accounting for the weak relationship between remittances and the rest of the 
domestic economy and this implies that relative spillover effects of remittances on domestic output and employment might remain weak if not redirected using specific policies. This is the result of an empirical study carried out by Agu (2009) using a four-sector medium scale macro-econometric model namely production and supply, aggregate demand, external sector and money and prices with 49 variables comprising of 18 endogenous variables, 31 exogenous variables and 14 identities. It found very weak link between remittances and the real sector as well as components of aggregate demand with the exception of private consumption for which impact is marginally significant. In turn, however, it could not be confirmed that any of these macroeconomic variables drive remittances. The study recommends use of specific and directed incentives to both reduce the leakages and encourage investments of remittance proceeds in other (preferably real sector) alternatives as a specific developmental programme. On their part and in a bid to x-ray the relationship between some external sector crises and the GDP of Nigerian economy, Ezirim, et al (2006) empirically studied the impacts of external debt burden and foreign direct investment remittances on Nigeria economic growth. The modified Granger causality procedure was used to derive the relevant models while estimation followed the log-linear least squares procedure against annual Nigerian data from 1970 through 2001. The diagnostic test results indicate that the specified models possess satisfactory forecasting and explanatory powers.

The relative statistical results indicate the existence of dual causality between external debt and foreign investment burdens in the country. Evidently, the two economic problems do not contribute positively and significantly to growth in the output levels of Nigeria, ceteris paribus.

However, a study of the long-run and short-run relationship between worker remittances and economic growth in Pakistan during the period of 1976 to 2010 was undertaken by Khathlan (2012), adopting the autoregressive distributed lag (ARDL) test and the error correction model (ECM) techniques. The results demonstrate the existence of a positive and significant relationship between worker remittances and economic growth in the long-run and short-run in that country. Worker remittances act as an important source of foreign capital, while a significant component of Balance of Payment serves as a boom to the economy. The gross fixed capital formation has a positive and significant impact on economic growth in the short run. The negative role in the long run in the presence of such financial flows shows the inappropriateness of policy measures aimed at boosting real sectors of the economy. FDI has a positive and significant impact on economic growth in the short run and long run.

An attempt to investigate the impact of migrants' remittances on economic growth in sub Saharan Africa with special reference to Nigeria, Ghana and South Africa was made by Ikechi and Anayochukwu (2013). Migrant's remittances were found to have impacted positively on the economic growth of the aforementioned economies with the greatest impact on South Africa, followed by Ghana and Nigeria. In terms of causality relationships, migrants' remittances are seen to granger cause economic growth in South Africa and Ghana, though the impact was felt more in South Africa than in Ghana. The situation was different for Nigeria, where economic growth was seen to granger cause migrants' remittance. Consequently, the study recommended that there is need for prudence in the management of funds sent home by migrants. Such monies are expected to be channeled into productive ventures and not for profligacy. To reap the full benefits of improved migrant's remittances, Sub Saharan Africa must create an investment climate that is alluring to Africans in the diasporas.

In a related study by Audu (2012), an attempt was made towards evaluating the macroeconomic effect of remittances on the Nigerian economy. Using data which is basically secondary that spans through forty-one years (1970-2010) it assesses the relative importance of the socio-political and economic determinants of remittance inflow in Nigeria using an Error Correction Mechanism. It was found that altruism is important for remitting, as per capita income differentials, gross capital formation, official Nigerian migrant remittances and economic/political freedom are significant and positive, implying that remittances are countercyclical in nature. However, there is evidence to suggest that the relationship between per capita income and worker's remittances is not linear-positive at low level of income and negative at higher income. The result also shows that the development of the financial sector would encourage remittance inflow although this is not robust to the differential specification.

\section{Methodology}

The research design adopted in this paper is aimed at empirically determining the extent to which foreign capital flows have impacted on the growth performance of the Nigeria economy from 1982-2012. Secondary data was obtained from various sources, such as the Nigerian Bureau of Statistics (NBS), the Central Bank of Nigeria (CBN) and the World Bank reports. The research therefore adopted the ex-post facto research design in order to establish whether any significant relationship exist between the dependent and independent variables because the 
data used were historical in nature. This is appropriate because ex-post facto research aims at measuring and establishing the relationship between one variable and another or the impact of one variable on another, in which the variables involved are not manipulated by the researcher (Onwumere, 2005).

\subsection{Model Specification}

We utilized a general specification type of growth model as in the work of Bailliu et al. (2002). It was chosen due to its ability to accommodate both exogenous and endogenous growth estimates.

Under the model, real GDP is stated as a function of taxation, government expenditure, openness, Human Capital Development and inflation rate.

The model is explicitly specified as follows:

$$
G D P=a_{0}+\sum_{i-1}^{n} a_{1} A_{y}+e r
$$

Where: GDP $=$ Gross Domestic Product;

$a_{0}=$ intercept concept;

$a_{1}=$ coefficient that measures the relative performance of each variable.

$A_{i j}=$ Matrices containing the explanatory variables (row vectors of growth determinants);

The model is however modified in log-linear form as follows:

$$
\log G D P=a_{0}+a_{1} \log \text { Inflow }+a_{2} \log \text { outflow }+a_{3} \log \mathrm{Opn}+a_{4} H c d+a_{5} \operatorname{logIfr}+\text { er }(2)
$$

Where: GDP $=$ Gross Domestic Product;

Infow=Foreign Capital Inflows;

Outflow $=$ Foreign Capital Outflow;

Opn $=$ Openness of the Economy;

$\mathrm{HCD}=$ Human Capital Development Index;

Infr. $=$ Inflation rate;

$a_{1}, a_{2}, \ldots, a_{5}$ are the parameters to be estimated.

\subsection{Impact of the Structural Adjustment Programme (SAP)}

A dummy variable $\mathrm{D}_{1}(\mathrm{i}=0,1)$ was introduced to separate the exogenous fiscal effects of the pre-SAP era (i.e., 1980-1985) from the SAP and post-SAP era (i.e., 1986-2010). It enabled us to capture the change from a regulated to a de-regulated economy. The resulting equation following the introduction of the dummy variable is stated as follows:

$$
\log G D P=a_{0}+a_{1} \log I n f l o w+a_{2} \log O u t f l o w+a_{3} \log O p n+a_{4} \log H c d+a_{5} \log \operatorname{Inf} r+\sum i D i+e r(3)
$$

Where:

$D_{1}(i=0,1)$ takes a value of one (1) for each year, that there was an exogenous change in fiscal policy, and a value of zero (0), where there was no such change.

\section{Data Presentation and Analysis of Results}

The data obtained from various sources, such as the Nigerian Bureau of Statistics (NBS), World Bank Reports and the Central Bank of Nigeria (CBN) was subjected to statistical analysis. The data was analyzed with the aid of statistical software- the statistical package for social sciences (spas) version 17.0 and the following results were obtained: 
Table 1. Capital inflow, capital outflow and economic growth (1982-2012)

\begin{tabular}{lcccc}
\hline Regressor & Coefficient & Standard Error & T-ratio & Probability \\
\hline Constant & 1.12771 & 0.80497 & 1.4010 & 0.177 \\
Inflow & 0.22291 & 0.17729 & 1.2573 & 0.223 \\
Outflow & 0.61163 & 0.19153 & 3.1934 & 0.005 \\
Opn & 0.5620 & 0.32385 & 1.7369 & 0.098 \\
Hcd & -0.00553 & 0.10329 & -0.0535 & 0.958 \\
Infr & 0.01291 & 0.11357 & 0.1136 & 0.9911 \\
Dummy & 0.48771 & 0.24366 & 2.0016 & 0.059 \\
\hline
\end{tabular}

Source: SPSS computations, 2013.

The functional log-form equation of the estimation results is stated as follows:

$$
L N G D P=1.12771+0.2229 \text { Inflow }+0.61163 \text { Outflow }+0.562500 \text { pn }+0.00553 \mathrm{Hcd}+0.012911 \text { Infr }+0.48771 \text { Dum }
$$

Table 2. The T-statistics are in parentheses below each parameter estimate

\begin{tabular}{llll}
\cline { 2 - 3 } $\mathrm{R}^{2}$ & $=$ & 0.97883 \\
$\mathrm{R}^{2}$ & $=$ & 0.96824 \\
S.E. of regression (SER) & $=$ & 0.33244 \\
F-statistics $=\mathrm{F}(8.16)$ & $=$ & 92.4603 \\
D.W. statistics & $=$ & 2.3353 \\
Mean of dependent variable & $=$ & 13.4815 \\
S.D. of dependent variable & $=$ & 1.9494 \\
Residual sum of squares & $=$ & 1.7683 \\
\hline
\end{tabular}

The F-values are significant at $95 \%$ confidence level.

\section{Empirical Findings}

We observe that in general terms, the estimates of most of the statistics were within acceptable ranges and also that the overall goodness-of-fit of our model was quite satisfactory.

The coefficient of Multiple Determination $\mathrm{R}^{2}$ was 0.9788 implying that approximately 98 per cent of the systemic variations in economic growth were explained by the independent variables. Most of the independent variables thus have a high explanatory power. The Adjusted R-bar square $\left(R^{2}\right)$ had a coefficient of 0.9682 , implying that about 97 per cent of the systemic variations in economic growth were adequately accounted for by the model, leaving only 3 per cent to autonomous influences after adjusting for the degree of freedom at 5 per cent level of significance. The F-statistic of 92.46 attested to the goodness-of-fit of the parameter estimates. The SER value of 0.33 confirmed the reliability and predictive power of the model. The Durbin-Watson (DW) auto-correlation test estimate of 2.335 provided reasonable proof of the absence of any auto-correlation disturbances, thus confirming that the standard errors were minimized.

The Foreign Capital Inflows variant (Inflow) which was one of our explanatory variables of prime focus had a positive and significant effect on the GDP, which is an indication that it exerted considerable influence as a key fiscal policy instrument of economic growth over the stated period. Also the Foreign Capital Outflow variant (Outflow) which was another of our explanatory variables of prime focus also had a positive and significant effect on the GDP, which is another indication that it exerted considerable influence as a key fiscal policy instrument of economic growth over the stated period.

The Openness variant (Opn) which was also one of the explanatory variables used to ascertain the growth performance of the economy, had a positive and significant effect on the GDP, which is another indication that it exerted considerable influence on economic growth over the stated period. On the other hand, the Human Capital Development variant (Hcd) which was also one of the explanatory variables used to ascertain the growth performance of the economy had a negative and insignificant effect on the GDP. The implication is that it did not exert much influence on economic growth over the stated period.

Finally, the inflation rate variant (Infr) which was the last of our explanatory variables used to ascertain the growth performance of the economy had a positive sign with GDP. It was however; statistically insignificant 
which points to the severity of the inflationary pressure brought to bear on the economy over the stated period.

The Dummy Variable $\mathrm{D}_{1}$ which had a coefficient value of 0.4877 and a t-ratio of 2.0016 was thus statistically significant. This is an indication that SAP exerted considerable influence on economic growth over the stated period. Finally, the inflation rate variant (Infr) which was the last of our explanatory variables used to ascertain the growth performance of the economy

\section{Summary and Conclusion}

The study is aimed at evaluating the relationship between Foreign Capital Inflows and Outflows, Openness of the Economy, Human Capital Development Index, Inflation rate and the gross domestic product which is the proxy for economic growth. Foreign Capital Inflows variant (Inflow), Capital Outflow variant (Outflow), Openness variant (Opn) and inflation rate variant (Infr) have positive and significant effect on the GDP. Human Capital Development variant $(\mathrm{Hcd})$ which is also an explanatory variable to ascertain the growth performance of the economy has a negative and insignificant effect on the GDP.

The implication of the findings is that all the explanatory variables of this study with the exception of Human Capital Development(Hcd) exerts significant and positive influence as key fiscal policy instrument in determining the growth performance of Gross Domestic Product (GDP) which is the proxy for growth of Nigeria economy. Currently Nigeria annual budget to a greater extent is hinged on foreign capital inflows from crude oil and gas exports, remittances and to a lesser extent, though significant too, on foreign capital outflows. Outflows are sources through which capital investments such as fixed assets and other specialized goods and services for economic transformation accrue to Nigeria.

However, the study done by Mallik and Chowdhury (2001) supports our findings with respect to inflation and GDP. They studied four countries namely Bangladesh, India, Pakistan, and Sri Lanka and found a positive and significant relationship between inflation and economic growth. It was emphasized that though moderate inflation promotes economic growth, faster economic growth absorbs into inflation by overheating the economy. This implies that within a certain acceptable threshold, inflation is vital in greasing the wheels of the growth and development machinery of any economy. The result is also in line with the findings of Khathlan (2012) and Ikechi and Anayochukwu (2013) but opposes the evidence portrayed in Audu (2012) and Agu (2009).

In conclusion, the result of this study will provide a reference point for fiscal policy setters in marshalling out macroeconomic policies for the Nigerian nation. Foreign capital flows should be vigorously pursued and enhanced to provide a buffer to the nations dwindling internally generated revenue (IGR) amidst astronomically growing population. The place of inflation in catalyzing growth and development in Nigeria should not be over-emphasized. However, single digit inflationary rate should be targeted by all concerned.

\section{References}

Agu, C. (2009, July). Remittances for growth: A twofold analysis of feedback between remittances. Financial Flows and the Real Economy in Nigeria, Paper Presented at the African Econometric Society Conference, Sheraton Hotel, Abuja.

Agu, C. (2009). The remittance service industry in Nigeria: An assessment. Background Paper for Africa Migration Project Migration and Remittances Team, Development Prospects Group: The World Bank, Washington, DC.

Audu, N. P. (2010). Foreign direct investment, economic growth and export performance in Nigeria: An error correction model. African Journal of social Sciences, 1(2), 53-63.

Aurangzeb, \& UI Haq, A. (2012). Impact of foreign capital inflows on economic growth in Pakistan. European Journal of Economics, Finance and Administrative Sciences, 46.

Bailliu, J., Lafrance, R., \& Perrault, J. (2002, June). Does exchange rate policy matter for growth. Bank of Canada, Working Paper.

CBN. (2009). Statistical bulletin. Central Bank of Nigeria.

Englama. (2009). The economics of Remittances, theories and issues-Paper presented at a high level Regional Seminar on International remittances for economic development. West African Institute of Financial and Economic Management Gambia.

Ezirim, B., Chinedu, M., Muoghalu, I., \& Emenyonu, E. N. (2006). Can the St. Louis model effectively explain output-debt relation in an emerging African country? Paper Presented at the Annual Conference of the American Academy of Accounting and Finance in New Orleans, Louisiana, December, 9-11. 
Hernandez-Coss, R., \& Egwuagu, B. (2007). The UK-Nigeria remittance corridor, chakllenges of embracing formal transfer systems in a dual financial environment. Washing, DC. World Bank working paper No. 92.

Iheke, O. R. (2012). The effect of remittances on the Nigerian economy. International Journal of Development and Sustainability, 1(2), 614-621.

Ikechi, K. S., \& Anayochukwu, O. B. (2013). Migrant's remittances and economic growth in Sub Saharan Africa: Evidence from Nigeria, Ghana And South Africa.Interdisciplinary Journal of Contemporary Research in Business Research, 4(10).

IMF. (1999). World economic outlook. International Monetary Fund. Washington, DC.

Khathlan. (2012). The link between remittances and economic growth in Pakistan: A boon to economic stability. British Journal of Economics, Management \& Trade, 2(3), 167-185.

Mallik, G., \& Chowdhury, A. (2001). Inflation and economic growth: Evidence from South Asian Countries. Asian Pacific Development Journal, 8(1), 123-135.

Nkoro, E., \& Furo, A. O. (2012). Foreign capital inflows and economic growth in Nigeria: An empirical approach. Academic Journal of Interdisciplinary Studies, 1(2).

Onwumere, J. U. J. (2005). Business and economic research methods. Lagos: Don-Vinton Limited.

Udah, E. B. (2011). Remittances, human capital and economic performance in Nigeria. Journal of Sustainable Development in Africa, 13(4).

\section{Copyrights}

Copyright for this article is retained by the author(s), with first publication rights granted to the journal.

This is an open-access article distributed under the terms and conditions of the Creative Commons Attribution license (http://creativecommons.org/licenses/by/3.0/). 